\title{
Three Groundwater Candoninae (Ostracoda) from Romania
}

\author{
Dan L. Danielopol*
}

\section{SUMMARY}

Description of Mixtcandona botosaneanui. Mixtacandona löffleri and Phreatocandona motasi, is presented. The first two species belong to the group laisi-chappuisi and have been found in porous and karstic aquifers in Southwest Romania in or a near the Lower Danube Valley. Phreatocandona motasi, occurs in a porous aquifer in the Olt Valley, at Jiblea, near Calimanesti. Biogeographical information on the present distribution of the Mixtacandona of the group laisi-chappuisi and on the subterranean Candoninae from the Lower Danube Valley in Romania is given.

During 1967 and 1971 I had the opportunity to sample groundwater fauna in the Lower Danube Valley (between Berzasca and Fetesti as well as in several valleys of the Danube tributaries i.e. Jiu (at Tirgu Jiu), Olt (between Turnu Rosu and Rimnicu Vilcea), Arges (at Hotarele and Heresti, near Bucharest), Buzau (between Intorsura Buzaului and Cislau), Iza (between Sacel and Sighetu Marmatiei), Somes (at Cimpia Turzei), Crisul Repede (between Valea Draganului and Vadu Crisului), The groundwater fauna was sampled in the large wells already dug in the alluvial sediments and used by the habitants for drinking water supply. In collaboration with D. Dancau, E. Serban and I. Tabacaru we investigated the fauna of about 250 wells. Mr. L. Botoseanu (Bucharest) offered me a collection of ostracods from the Banat caves, which he previously had sent to Prof. H. Löffler (Vienna). This latter recognised several new specices but has no time to describe them.

In the present paper I shall describe three species belonging to the genus Mixtacondona Klie and Phreatocandona Dan. The two Mixtacandona species have close affinities with ground-

"Limnologisches Institut, Oesterreichische Akademie der Wissenschaften. gaisberg 116, A - 5310 Mondsee, Austria, 

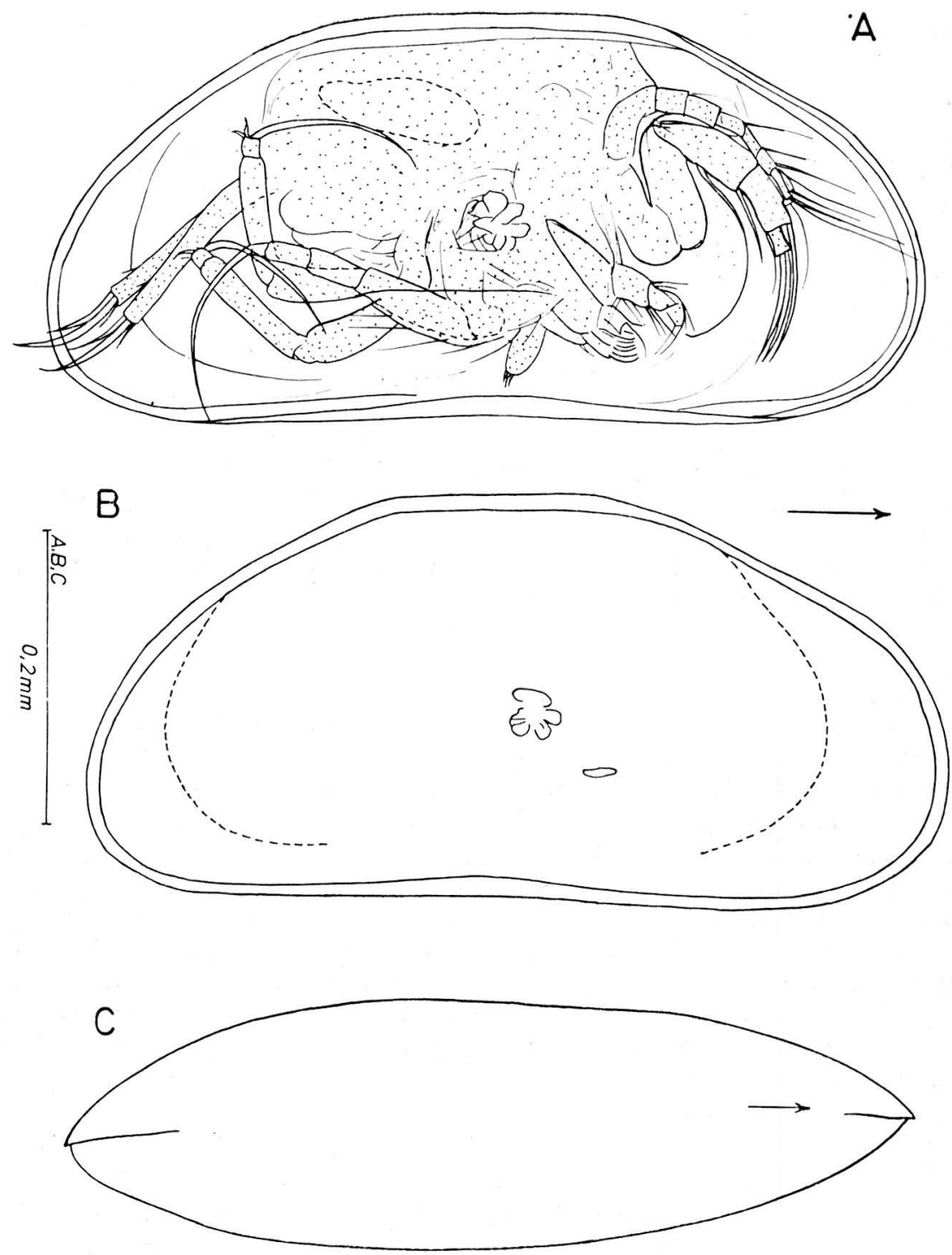

Fig. 1 - Mixtacandona botosaneanui Dan., female, A-general aspect, left valve rẹmoved; B-right valve; C-carapace, dorsạl view, 
water Candonids living in the Upper Danube Valley and its tributaries, in Austria.

The description and the notations of the ostracod follows the system used by Danielopol and Cvetkov (1979) (l-long, s-short, c-claw).

\section{SYSTEMATICS}

Mixtacandona botosaneanui, Danielopol, 1978b (1).

Holotype. A female deposited at the Institute of Speology «E. G. Racovitza», Bucharest.

Type locality. The cave Zamonita in the Mounts Almajului, Jud. Caras Severin (see for location, Botosaneanu and Negrea, 1972).

\section{Material}

A dozen of specimens (adult females and juveniles) collected in the Pestera Zamonita by Mr. L. Botosaneanu (sample $\mathrm{nr}$. 1118) one female collected in a well dug into a porous aquifer in the village Berzasca, near Moldova Veche (see for location, Dancau and Danielopol, 1972).

\section{Description}

Carapace and valves (fig. 1, A-C, 2A): The shape is elongated, oblong small size $(0,57-0,6 \mathrm{~mm}$ length); dorsum almost straight; large cardinal angles present: anterior and posterior margine broadly round venter straight; greatests height medial, about $45 \%$ the lingth. In dorsal view: narrow elliptic with pointed extremities; greatest width less than $1 / 3$ rd of the length. Internally: maximum width of the vestibulum, about $15 \%$ the length, anteriorly, and $12 \%$ the length, posteriorly. In lateral view the inner margin appears separated from the outer margin. Radial pore canals short, more numerous on the anterior margin. The position of the adductor muscle scars: in the central part of one valve. The outer lamella is smooth without ornamentation. The left valve slightly larger than the right one.

Eyes: invisible.

Antennule fig 2,B,C): Length ratios of segments 2-7 are 2/1, 6/1, 4/1, 5/1, 5/2, 2. Chaetotaxy: II =A-ls, P-O; III=A-ls, P-O; IV= A-2l, P-ls; V=A-2l, P-ls; VI=A-2l, P-2s; VII=lc, 2l, Ya. The two posterior setae of the 6th segment of equal size, a little longer than the distal segment. This latter with a strong sclerotized

(1) Species dedicated to $\mathrm{Mr}, \mathrm{L}$, Botosaneanu, who first collected the species, 

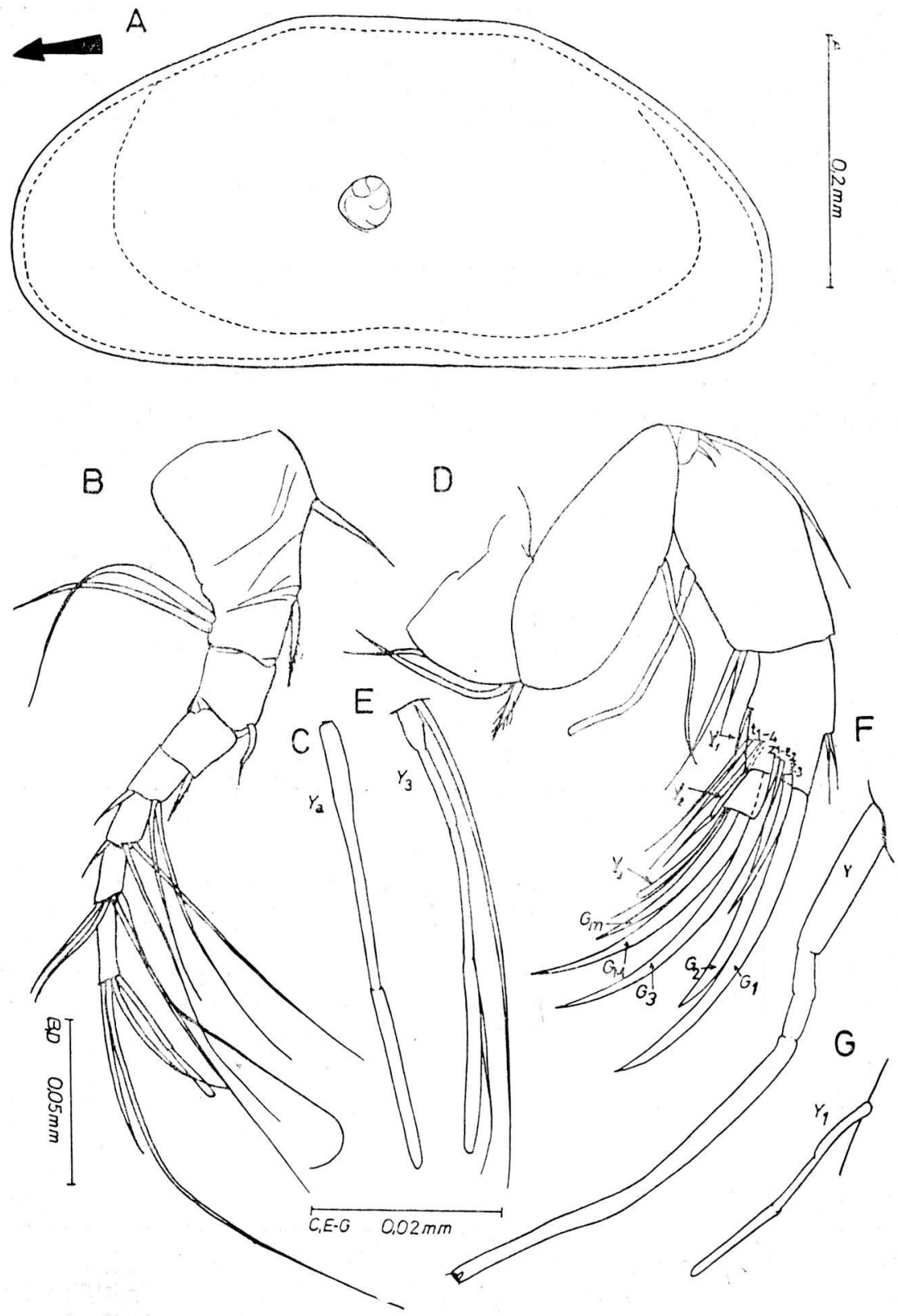

Fig. 2 - Mixtacandona botosaneanui Dan., female. A-left valve; B-antennule; C-aesthetasc Ya; D-G - antenna; D-general aspect; E-aesthetasc $\mathrm{Y}_{3}$ and adjacent seta; F-aesthetasc $\mathrm{Y}$; G-aesthetasc $\mathrm{Y}_{1}$, 
seta (c), 2 unequal setae and an antennular aesthetasc Ya (the hyaline extremity represent $40 \%$ of the aesthetasc length).

Antenna (fig. 2, D-G): Exopodite with 2 short and one long setae. Endopodite 3 segmented. Chaetotaxy: I=P-Y,ls,1l; II+ III $=A-2 s, P-Y_{1}, t_{1}-t_{4} l Y_{2}, D-G_{1}, G_{2}, G_{3}, Z_{1}-Z_{3} ; \quad I V=G_{M}, G_{m}, Y_{3}, 2 l . \quad$ Th e aesthetasc $Y$ long (107\% the length of the lst endopodial segment).

The aesthetascs $Y_{1}-Y_{3}$ with a distal hyaline extremity. The $Z_{1}-Z_{3}$ setae inserted on the lateral side. The length of the claw $G_{1}$ represents $1^{1 / 2}$ times of the lst endopod al segment. The length of the $G_{2}$ represents about $2 / 3 \mathrm{rd}$ of the $G_{1}$ length. The length ratio $G_{\mathrm{m}} / \mathrm{G}_{\mathrm{M}}$ is $5,4 / 7,3$.

Mandible (fig. 3,A): The length ratio of the last 2 segments of the mandibular palp is $2 / 1$. The chaetotaxy of the palp: $\mathrm{I}=$ I-1l (smoot) 11 (plumose), Is (smooth with a filamentous tip), Is (conate-papose) II =E-21, I-3+2 (papose); III =-31, I-3l; IV = lc, lc (fused to the segments and distally pectinated), 2l. The 2nd segment on the interior side with 2 rows of setae; one has 3 long setae, the second 2, one long and one shorter.

Maxillule (fig. 3,B): The 3 endites with stout setae. The maxillula palp with 4 papose setae on the proximal segment and 6 setae on the distal segment.

Maxilla (fig. 3,C): Exopodite and endopodite, each with 3 short setae. Masticatory lobe with 12 setae.

lst thoracic limb (fig. 3,D): Chaetotaxy: Pr. - O; I-O; II-ls; III -ls; IV-ls, lc,ls. The length of the distal claw is $1^{1 / 2}$ times of the lst endopodial segment.

2nd thoracic limb (fig. 3E) : Chaetotaxy: Pr. $=\mathrm{E}-2 \mathrm{~s}, \mathrm{I}-1 \mathrm{~s}, \mathrm{I}=-0$; II + III $=E-1 s ; I V=11,2 \mathrm{~s}$. The 2 nd and 3rd endopodial segment are fused and a shallow intersegmental groove is visible on the outer side.

Furca (fig. 3,F): The distal claws nearly equal; the anterior claw $2 / 3$ rd of the furcal shaft. The anterior and posterior setae are tiny.

Male unknown.

\section{Discussion}

This species was first recognised by Professor $H$. Löffler when he studied the ostracod collection of Mr. L. Botosaneanu. It has close affinities with $M$. transleithanica (Löffler, 1960) from Austria and with M. chappuisi (Klie, 1943) from Romania. M. translethanica (Löffler) has a small vestibulum $(12,5 \%$ the length). The ventral inner margin, in lateral view, appears fused with the outer margin. The cleaning leg has the 2nd and the 3rd endopodial segments fused and an outer circular intersegmental groove. Löffler (1960) wrote: «Der Putz- 

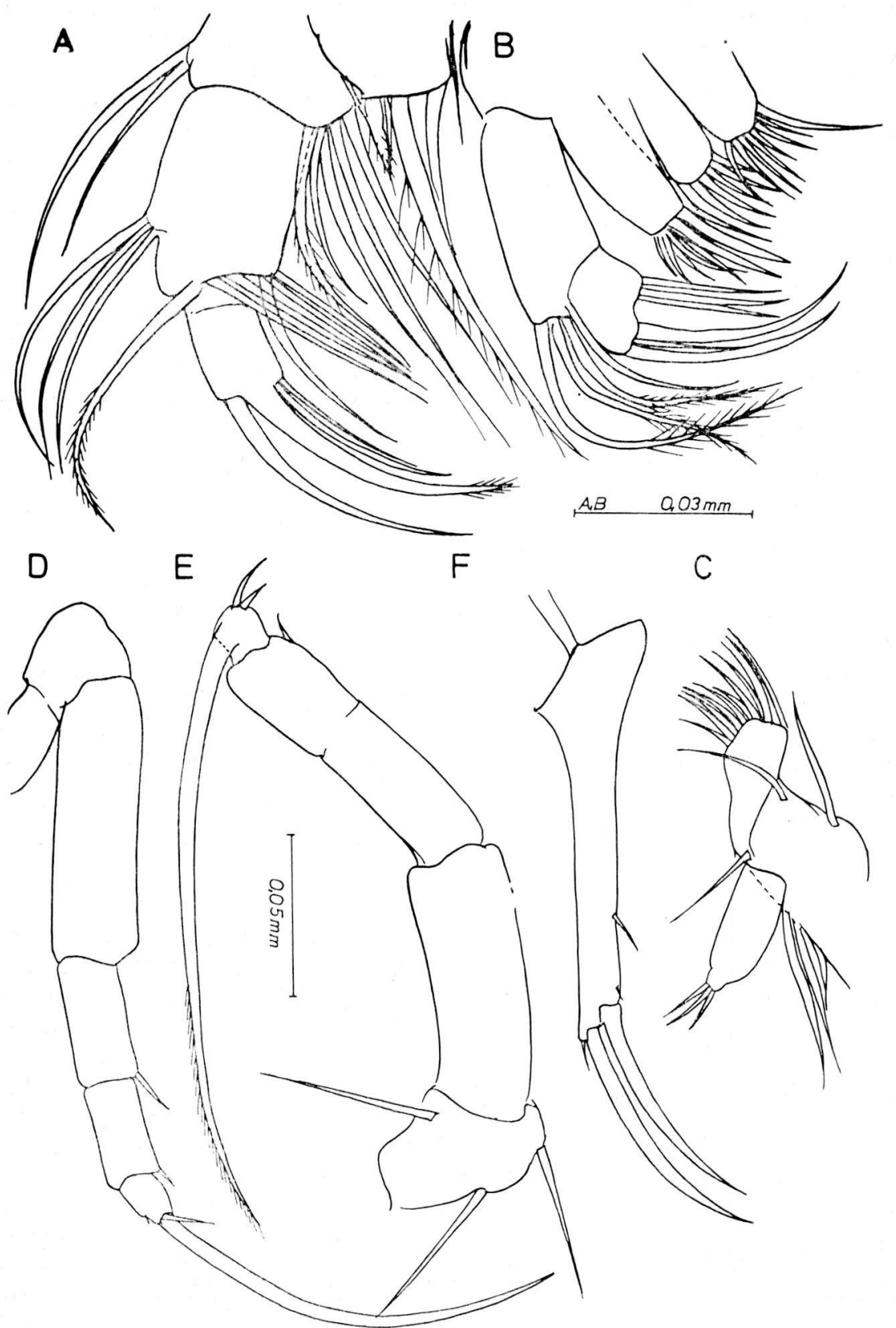

Fig. 3 - Mixtacandona botosaneanui Dan., female. A-mandibular palp; B-maxillule; C maxilla; D-lst thoracic limb; E-2nd thoracic limb; F-furca. 
fuss trägt am Grundlied drei Borsten, sein vorletztes Glied is in zwei Scheinglieder geteilt». p. 27.

The female of $M$. chappuisi (Klie) collected from alluvial sediments of the Dragan Valley (see Klie, 1943) has a carapace similar to that of $M$. botosaneanui Dan. $(0,58 \%$ length) the maximal heigth $45 \%$ the length. The anterior and posterior vestibules are slightly larger (17\% and $19 \%$ the length) than those of $M$. botosaneanui. The antennular chaetotaxy is: $\mathrm{II}=\mathrm{A}-\mathrm{ls}$, P-O; III =A-ls, P-O; IV=A-1l, P-ls; V=A-O,P-O; VI=A-11,P-2s; VII=lc,2l,Ya. The antenna has on the anterior side of the 2nd endopodial segment only one short seta; The aesthetasc Y represents $87,5 \%$ on the lst endopodial segment. The male of $\mathrm{Mi}$ xtacandona chappuisi illustrated by Klie, 1943 (fig. 4, 5, 10) was found in a well in Bratca and belonges to a species close to Mixtacandona laisi (Danielopol, in preparaiton).

\section{Mixtacandona löffleri. Danielopol, 1978b (1).}

Holotype. A female deposited at the Limnologisches Institute, Vienna.

Type locality. Ada Kaleh Island, Danube (jud. Mehedinti). Material

3 males and 6 females collected in a well in Ada-Kaleh Island, near Orsova (leg. A. Danielopol and D.L.D.), 1 female in a well at Virciorova, near Ada-Kaleh (leg. E. Serban and D. Dancau) and 1 female and several juveniles in a well at Moldova Noua, Jud. Caras-Severin, leg. E. Serban (see for location Dancau and Danielopol, 1972).

\section{Description}

Carapace and valves (fig. 4,A-F): trapezoidal, small size (0.63-0.64 mm length), no sexaual dimorphism; dorsum almost straight, large cardinal angles present; anterior margin broadly rounded; venter straigth. Greatest height in the central area, about $51 \%$ the length on the left valve and $50 \%$ on the right one. In dorsal view the carapace is narrow elliptical with pointed extremities; greatest width less than $1 / \mathrm{rd}$ of the length. The left valve sleghtly larger than the right one. Internally: maximum width of the vestibulum about $18-20 \%$ anteriorly and 14$15 \%$ posteriorly. In lateral and ventral view the inner margin appears separated from the outer margin. Radial pore canals short, open subterminally on the outer lamella; they are more numerous on the anterior and antero-ventral margin and decreas in number on the postero-ventral and posterior margins.

1) Species dedicated to Prof, H. Löffler, Limnologisches Institut, Vienna. 

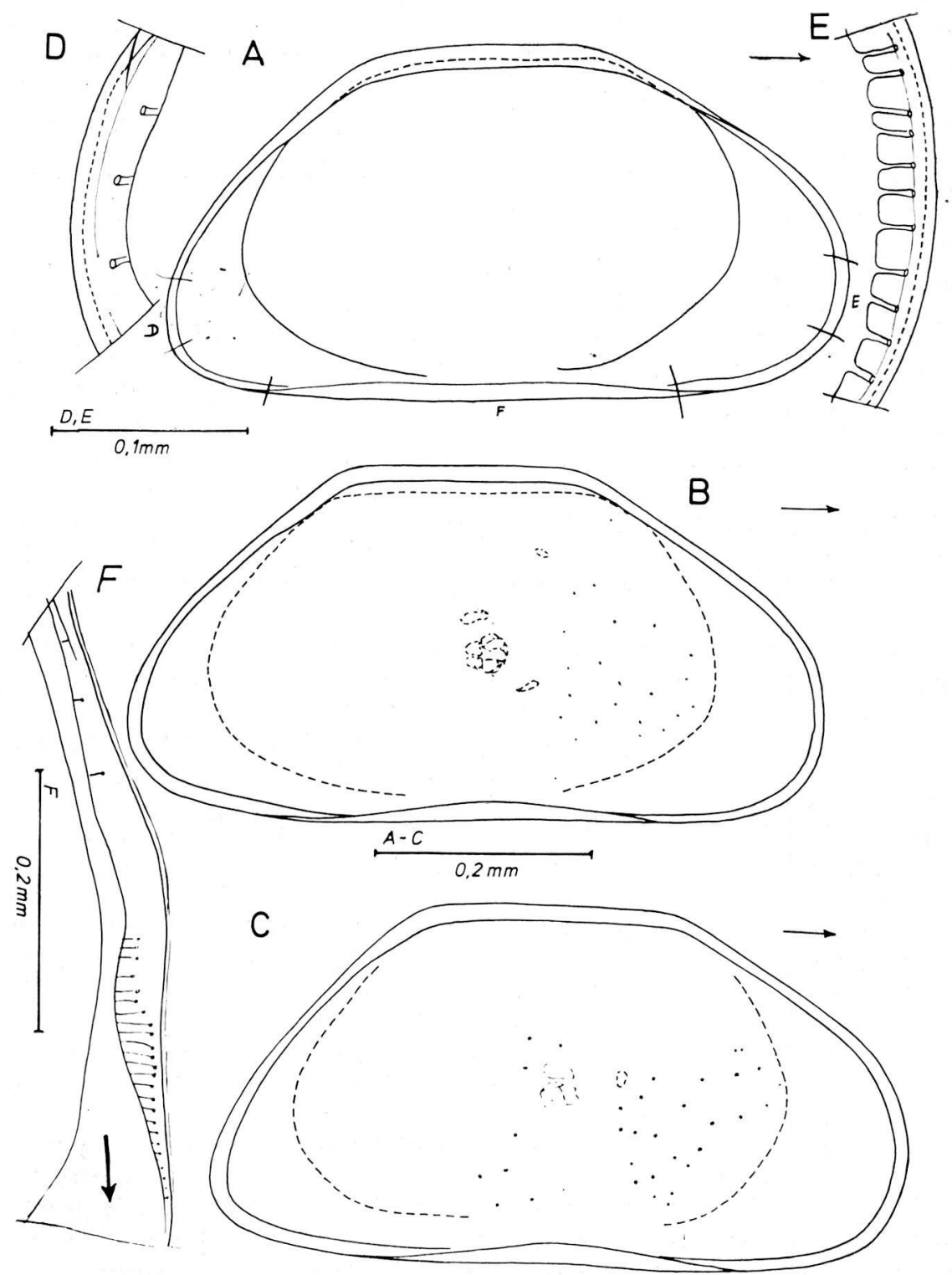

Fig. 4 - Mixtacandona löfleri Dan., carapace and valves. A, B, D, F-male; Cfemale; A, D, E, F-left valve; A-general aspect; D-F - details of the anterior, posterior and ventral margins; B, C . carapace. 
The position of the adductor muscle scars: in the central P. Ornamentation: outer lamella smooth.

Eyes: invisible in living specimens.

Antennule similar to those of $M$. botosaneanui. Length ratio of segments 2-7 are: $3,5-2,8-2,5-2,3-2,6-3,8$. Chaetotaxy: II=A-ls, P-O; III=A-ls, P-O; IV=A-2l,P-ls;V=A-2l,P-ls; VI $=\mathrm{A}-2 \mathrm{l}, \mathrm{P} 2 \mathrm{~s} ; \mathrm{VII}=\mathrm{lc}, 2 \mathrm{l}, \mathrm{Ya}$.

Antenna (fig. 5, A-D, 6, A-B): Exopodite with 2 short and one long setae. Endopodite dimorphic; female: 3 segmented; chaetotaxy: I =P-Y, ls,1l; II + III =A-ls, P-Y ${ }_{1}, \mathrm{t}_{1}-\mathrm{t}_{4} \mathrm{l}, \mathrm{Y}_{2}, \mathrm{D}-\mathrm{G}_{1}, \mathrm{G}_{2}, \mathrm{G}_{3}, \mathrm{Z}_{1}, \mathrm{Z}_{2} ; \mathrm{IV}=$ $\mathrm{G}_{\mathrm{M}}, \mathrm{G}_{\mathrm{m}}, \mathrm{Y}_{3}, 2 \mathrm{l}$.

The aesthetasc $\mathrm{Y}$ long $(102 \%$ of the length of the lst endopodial segment). The distal part of the aesthetascs $Y_{1}-Y_{3}$ is hyaline and the outer surface is covered with minute pits. The $\mathrm{z}_{1}$ small; $\mathrm{z}_{2}$ twice the length of the distal endopodial segment; both $z_{1}$ and $z_{2}$ inserted on the lateral side of the segment. The length of the claw $G_{1}$ is $142,6 \%$ of the lst endopodial segment. The length of the $G_{2}$ represents about $61 \%$ of the $G_{1}$ length.

The length ratio of $G_{m} / G_{M}$ is about $2 / 3$. The male: 4 endopodial segments; $t_{2}, t_{3}$ rod-shaped, $z_{1}$ inserted on the medial side of the segment. The length ratios $G_{1} / I=1,5$ and $G_{2} / G_{1}=1 / 3$.

Mandible (fig. 6, C, D): The gnathobasis with 7 pointed teeth and a papose guide seta. The chcaetotaxy of the mandibular palp is: I=I-1l (smooth), 11 (plumose), 1s (smooth with filamentous tip), 1s (conate papose); II =E-2l, I-3+2 (papose); III $=\mathrm{E}-3 \mathrm{l}, \mathrm{D}-3, \mathrm{I}-2 \mathrm{l}, \mathrm{ls} ; \mathrm{IV}=\mathrm{lc}$, lc (fused to the segment and distally pectinated), 21.

Maxillule: similar to those of $M$. botosaneanui.

Maxilla (fig. 5, E-G): Exopodite with 3 setae. Endopodite dimorphic. Female, with a single segment and 3 distal setae; the central one longer. Male: the clasping organs slightly asymmetric; the left one inflated ventro-distaly; the right endopodite resembling the left one but without a ventro-distal protuberance. (Note that the clasping organ in the figure $5, G$ is in a slightly oblique position).

1st thoracic limb (fig. 7,B): Chaetotaxy: $\mathrm{Pr}-\mathrm{O} ; \mathrm{I}=\mathrm{O}$; II=ls; III $=\mathrm{ls} ; \mathrm{IV}=\mathrm{ls}, \mathrm{lc}$, ls. The length of the distal claw is $144 \%$ of the 1st endopodial segment.

2nd thoracic limb (fig. 7, C): resembling those of $M$. botosaneanui.

Furca (fig. 7, D): the anterior claw about $60 \%$ of the shaft length. The posterior claw shorter $190 \%$ of the anterior claw length); anterior and posterior setae, minute.

The female genital lobe (fig. 7, D): flat, round posteriorly.

Hemipenis (fig. 8, A): peniferum with a lateral fingerlike lobe (a); the ventral margin (see arrow) of the medial lobe (b) largely bent toward the lateral side. The distal margin of the 


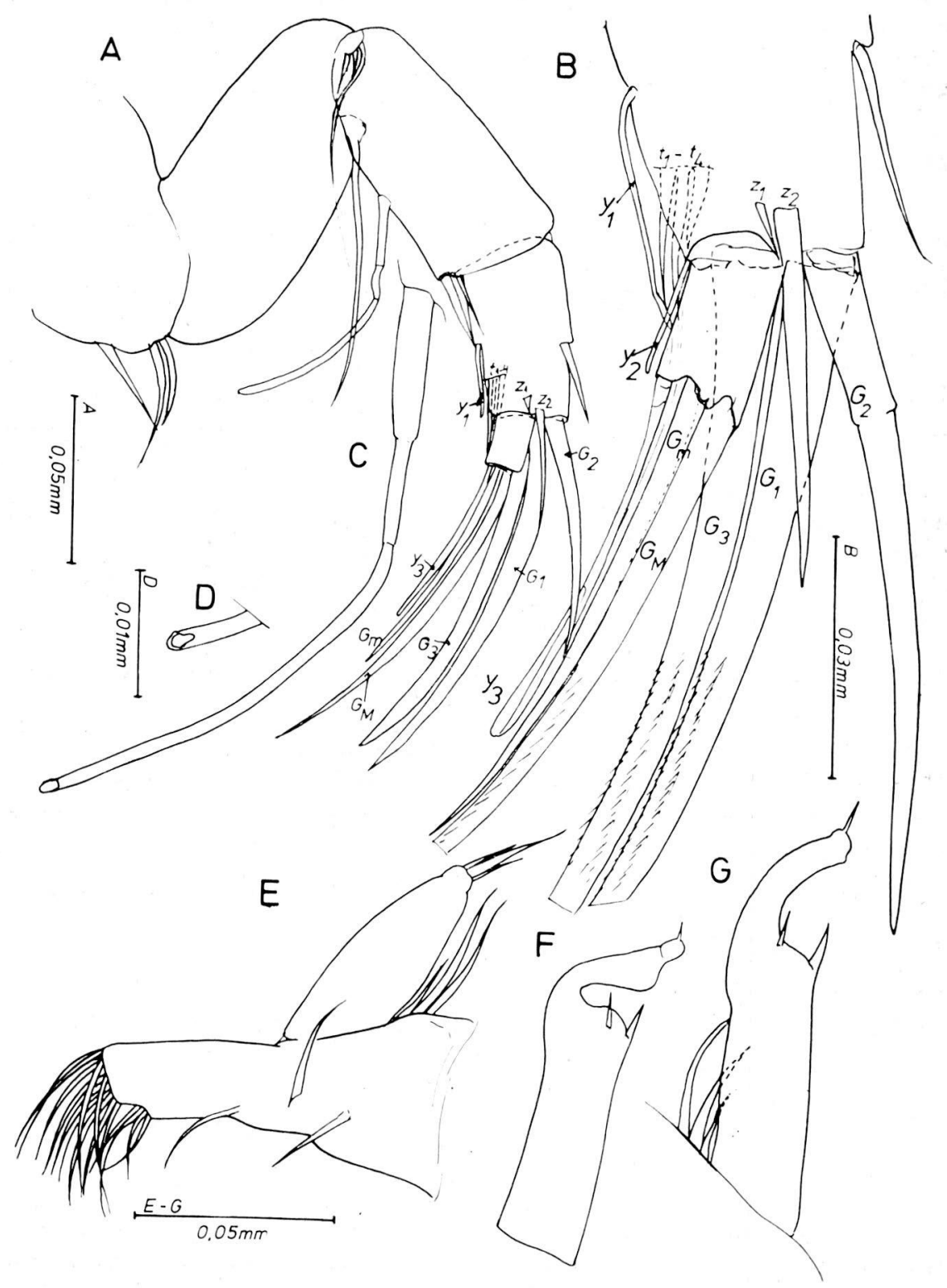

Fig. 5 - Mixtacandona löffleri Dan. A-E - female; F, G-male; A-D - antenna; A-general aspect; B-detail of the endopodite; C-aesthetasc Y; D-distal part of the aesthetasc Y; E-maxilla; F,G-left and right clasping organs. 
lobe D, (h), largely rounded. The bursa copulatrix (e) with a finger-like lobe on each side (Note that the hemipenis illustrated above should be in the post copulation-retroaction position): The medial sclerotized strip (c) with 2 distal arms .

\section{Discussion}

Mixtacandona löfleri shows close affinities with Mixtacandona laisi vindobonensis (Löffler, 1963) from the Upper Danube Valley, near Vienna. The male copulatory organ of $M$. laisi vindobonensis (fig. 8, E) differs from those of $M$. löffleri as follows: the distal tip (see arrow) of the medial lobe (b) is slightly bent toward the lateral side; the lobe $D(h)$ is less extruded from the peniferum; the peniferum is narrower than those of $M$. löffleri; the bursa copulatrix (e) does not display 2 lateral distal processes. The carapace height of $M$. laisi vindobonensis does not reach $50 \%$ of the length (tab. 1 ), opposed to $M$. löffleri, which exceeds it slighty. The male clasping organs of the maxilla are almost symmetric (fig. 8, $F, G$ ) in $M$. laisi vindobonensis (the ventro-distal protuberance of the left endopodite is poorly developed).

Table 1 - Carapace hight of Mixtacandona löfleri and Mixtacandona laisi vindobonensis.

\begin{tabular}{cccc}
\hline Taxa and location & $\begin{array}{c}\text { Nr. } \\
\text { specimen }\end{array}$ & $\begin{array}{c}\text { Height in } \% \text { of } \\
\text { length (mean } \\
\text { value) }\end{array}$ & $\begin{array}{c}\text { Confidence } \\
\text { limits }\end{array}$ \\
\hline
\end{tabular}

M. löffleri

(Ada-Kaleh Isl.)

9

51.44

$50.99-51.89$

M. Laisi vindobonensis

(Lobau-Eberschüttwasser)

19

45.73

$45.09-46.38$

Phreatocandona Danielopol, 1978b.

\section{Diagnosis}

Carapace elongated with the posterior end acuminated. Antennal exopodite with 3 short setae. The lst thoracic limb has on the 3rd endopodial segment a long seta which represents about double the length of this segment. The 2nd thoracic limb without setae on the first two endopodial segments; the distal segment bears three long setae.

Type-species. Phreatocandona motasi. 


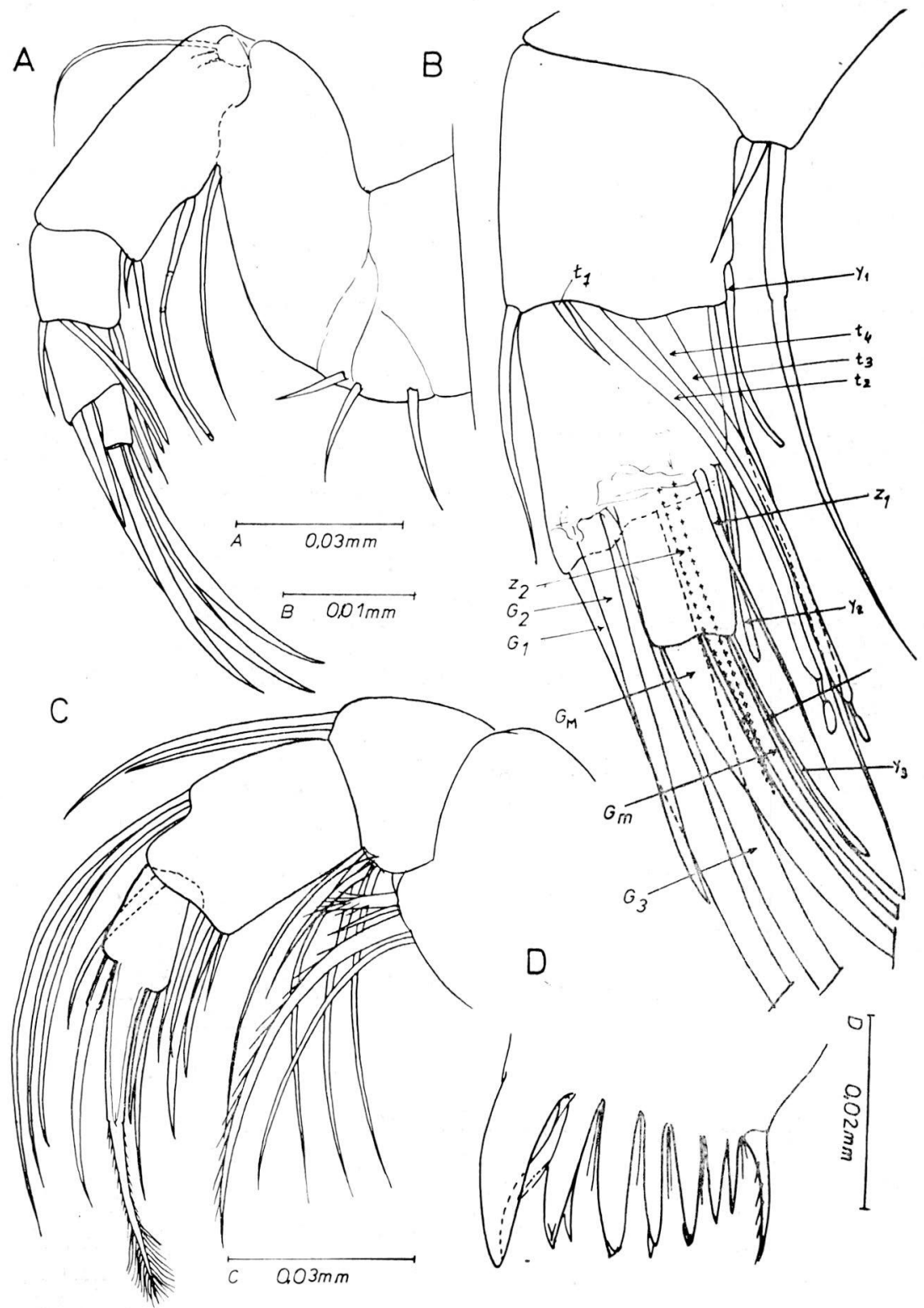

Fig. 6 - Mixtacandona löffleri Dan., male. A, B-antenna; C, D-mandible; A-general aspect; B-endopodite; C-mandibular palp; D-mandibular gnathobasis. 


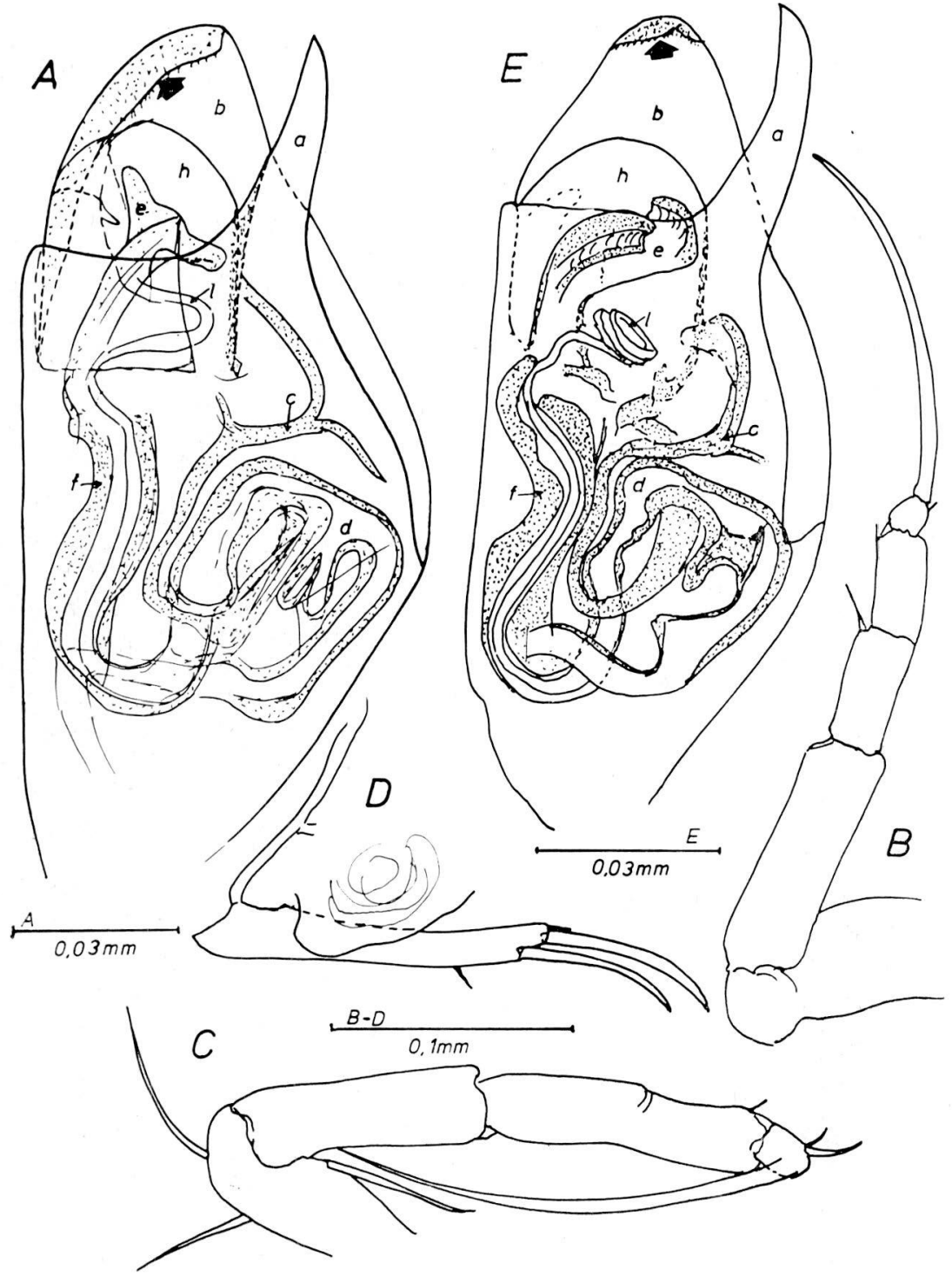

Fig. 7 - A-D-Mixtacandona löfleri Dan.; E-Mixtacandona laisi vindobonensis (Löffl.). A, E-male; B-D . female, A, E-hemipenis, lateral view; B-lst thoracic limb; C-2nd thoracic limb; D-furca and genital lobe. 


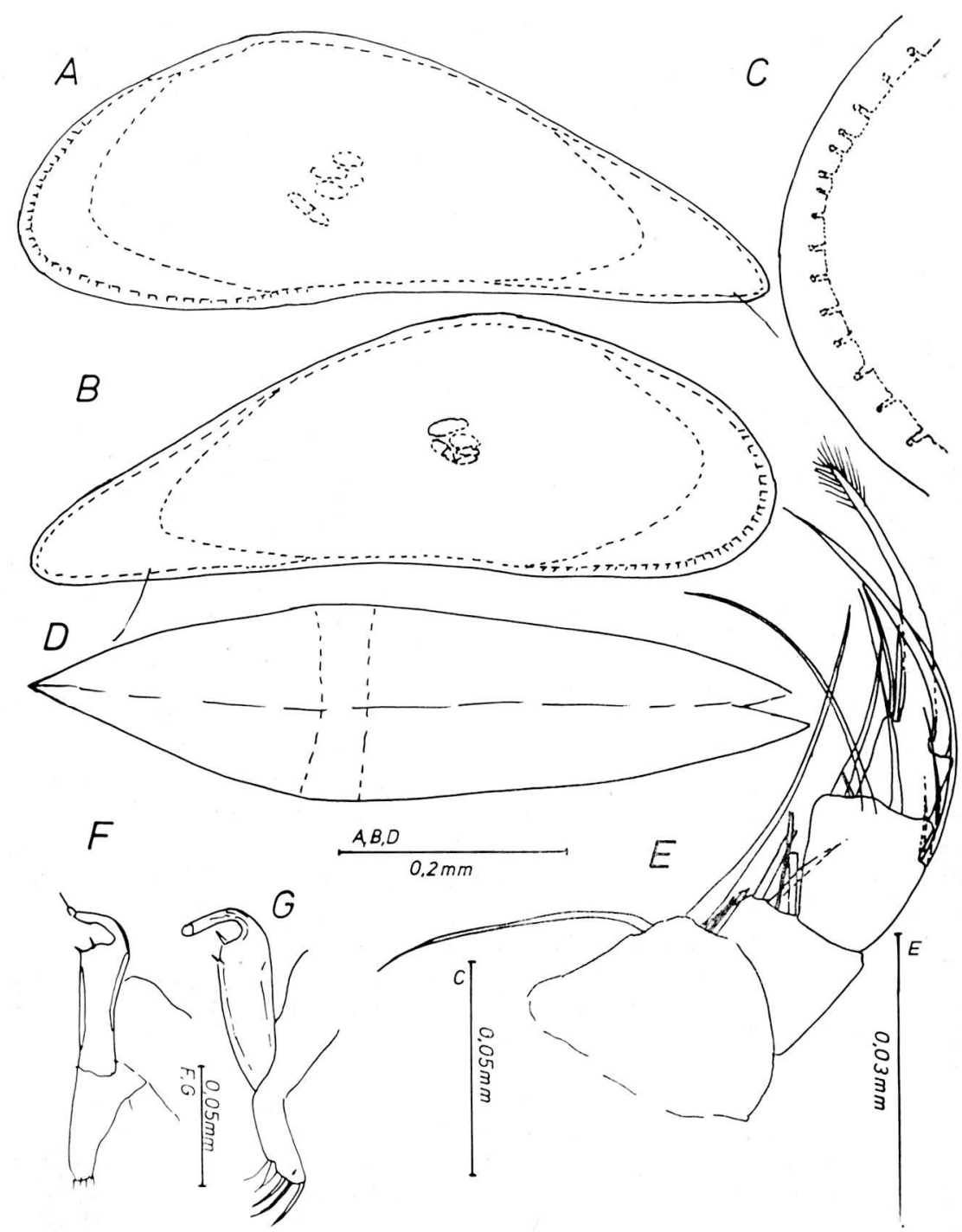

Fig. 8 - A-E - Phreatocandona motasi Dan., female. A, B - left and right valves, general aspect; C-anterior margin, left valve, detail; D-carapace, dorsal view; E-mandibular palp; F-furca and genital lobe. F,G - Mixtacandona laisi vindobonensis (Löffl.), male; F-left clasping organ; Gright clasping organ. 
Phreatocandona motasi, Danielopol 1978b.

Holotype. A female deposited at the Limnologische Institut, Vienna. Type locality. A well in Jiblea near Calimanesti in the Olt Valley (Jud. Valcea).

\section{Material}

3 females, 2 juveniles found in the well of Jiblea.

\section{Description}

Carapace and valves (fig. 8, A-D, 10): Thin calcareous lamellae; :

In dorsal view, anterior and posterior thirds, very pointed; sharp asymmetry of the valves, the left one is more elongated than the right one. The valves have the anterior margin strongly bent, the dorsal straight which in his posterior part forms with the ventral margin a sharp angle; the ventral margin slightly concave in the central third. The fused zone is narrow and traversed by short marginal pore canals; there are more canals on the anterior and antero-ventral margins than on the ventro-posterior one. The vestibullum less developed on the anterior side than on the posterior one; $(9 \%$ of the carapace length against $18 \%$ the length). The inner marginal line is strongly bent on the anterior and posterior sides.

Selvage and flange poorly developed. Hinge adont, the left valve has a dorsal groove. Maximal height (36\% the length) and width (29\% the length) in the anterior third. The adductor muscle scars in an antero-subcentral positions. Valves asymmetric, the left one larger $(0,65 \mathrm{~mm}$ length) than the right one $(0,64 \mathrm{~mm})$. Ornamenation: surface of the lamellae smooth.

Antenna (fig. 9, A-E): Exopodite with 3 short setae of equal length. Endopodite 3 segmented. Chaetotaxy: I=P-Y,ls,1l; II+ III $=A$-ls, $P-Y_{1}, t_{1}, t_{2} \quad\left(t_{3}, t_{4}\right.$ invisibile $), \quad D-z_{1}-z_{3}, G_{1}, G_{2}, G_{3} ; \quad I V=G_{M}, G_{m} 2 l$, $\mathrm{Y}_{3}$.

$\mathrm{G}_{1}$ represent $186 \%$ the length of the lst endopodial segment; $\mathrm{G}_{2}$, very small and slender, slightly exceeding the length of the distal segment. The $Y_{1}$ reduced. The $G_{m}$ is $1 / 5$ shorter than $G_{M}$. The distal part of the aesthetasc $\mathrm{Y}_{3}$ represents $30 \%$ of the total length.

Mandibular palp fig. (8, E): Chaetotaxy: I=I-1l (smooth), 11 (plumose), ls (papose). ls (smooth); II $=\mathrm{I}-3+1-2, \mathrm{E}-\mathrm{O}$; III $=\mathrm{I}-3 \mathrm{l}$, D-1l; IV-lc,lc (fused to the segment, distaly pectinated), 21.

Maxillular palp: 3 long and one short setae on the distal margin of the proximal segment. The 3 inner setae of the distal

(1) Species dedicated to to Prof. C. Motas (1891-1980). 


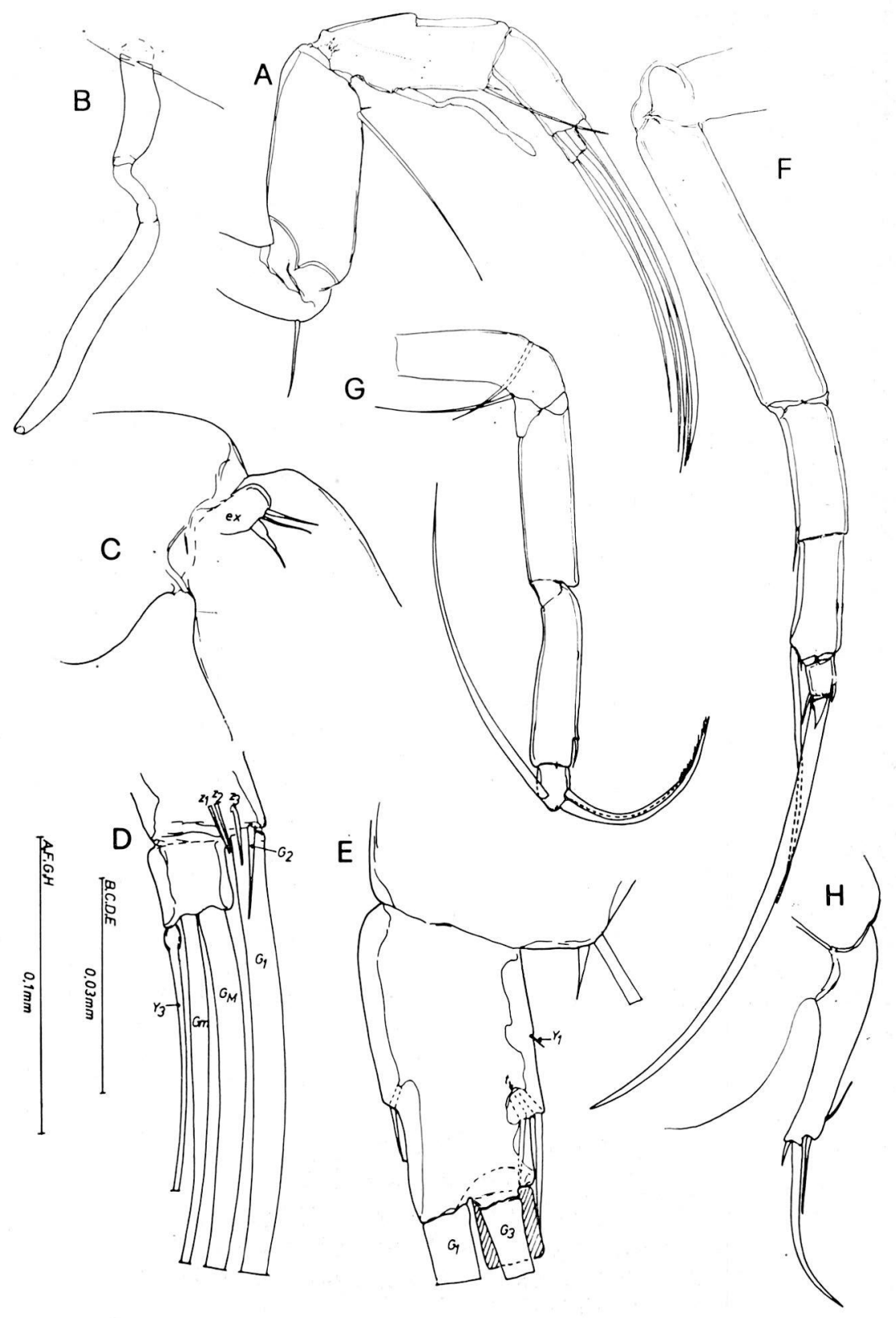

Fig. 9 - Phreatocandona motasi Dan., female. A-E - antenna; A-general aspect; B-aesthetasc Y; C-exopodite; E-lateral and medial view of the endopodite; F-lst thoracic limb; G-2nd thoracic limb; H-furca. 
segment are very short compared to the outer 2 claws (length ratio 1:2). On the anterior side of the distal margin of the proximal segment. The 3 inner setae of the distal segment are very short compared to the 2 outer "claws".

Maxilla: The endopodite with 3 short distal setae; Exopodite not visible.

lst thoracic limb (fig. 9, F): Chaetotaxy: $\operatorname{Pr}=\mathrm{O}$; I=0; II=ls; III $=11,1 s ;$ IV $=1 \mathrm{ls}, 1 \mathrm{lc}, 1 \mathrm{~s}$. The length of the distal claw is $144 \%$ the length of the lst endopodial segment. The long seta of the 3rd endopodial segments represents $55 \%$ of the distal claw.

2nd thoracic limb (fig. 9, G): Chaetotaxy: $\operatorname{Pr}=11, \mathrm{I}-1 \mathrm{l} ; \mathrm{I}=0$, $\mathrm{II}+\mathrm{III}=\mathrm{ls} ; \mathrm{IV}=3 \mathrm{l}$. There is no groove on the middle segmnt suggesting a rest of the intersegmentary joint. The distal segment with 3 setae; the length ratios are $1,3-2-3,2$.

Furca and genital lobe (fig. 9, H): The furcal shaft is short. The length ratios between the anterior and posterior setae and the anterior and posterior claws are: $1-2-3,1-6,8$. The anterior claw represents $86 \%$ of the furcal shaft. The genital lobe is round.

Eyes: invisible on living specimen.

Male unknown.

\section{Discussion}

The carapace resemble that of "Candona» fossiliformis (Mazepova, 1970) and that of the Mixtacandona of the group ljovuschkini (Danielopol and Cvetkov, 1979). The structure of the 2nd thoracic limb resembles those of Candona, Fabaeformiscandona and Pseudocandona (see Klie, 1938, b). No other candonid genera have 3 tiny setae on the anetnnal exopodite, a very long seta on the 3rd endopodial segment of the 2nd thoracic limb and the antennal aesthetasc $\mathrm{Y}_{1}$ and the antennal claw $\mathrm{G}_{2}$ very small. The furca with a strong asymmetry between the anterior and posterior claws is similar to Pseudocandona marchica (Hartw).

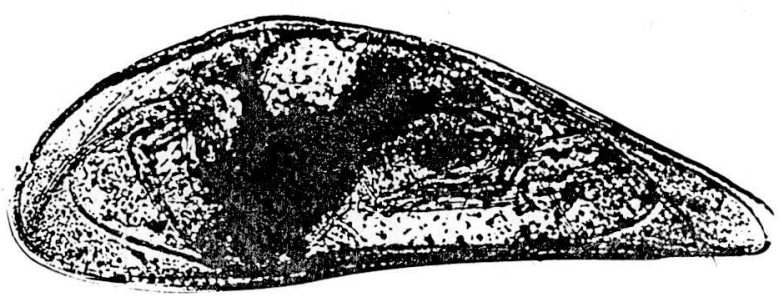

Fig. 10 - Phreatocandona motasi Dan., female (photomicrograph made by Dr, T, Orghidan, Bucharest), 


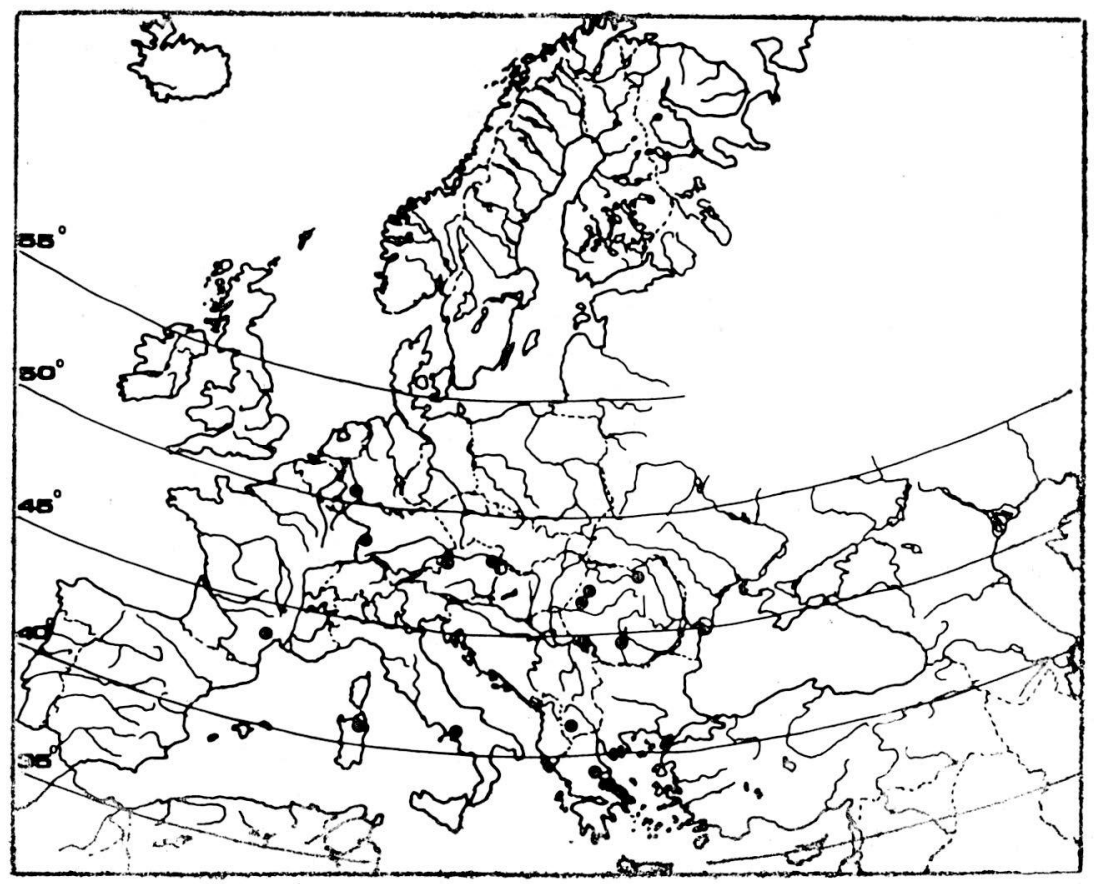

Fig. 11 . The geographic distribution of the Mixtacandona species belonging to the group laisi-chappuisi.

Phreatocandona motasi occurs in a well where other remarquable groundwater animals have been found i.e. Niphargus alutensis and Niphargopsis sp. (amphipods) (Dancau, 1971), Pseudocandona serbani (Danielopol, 1978b) (an ostracod) and a water mite belonging to the family Stygotrombidiidae.

\section{BIOGEOGRAPHICAL COMMENTS}

The Mixtacandona species of the group laisi-chappuisi are widely distributed in Europe (fig. 11). It must be noticed that this group of species does not occur in Northern Europe, in areas covered by ice during the Pleistocene. The other groups of Mixtacandona have more restricted distributions. The groupe ljovuschini and riongessa are located in East Europe (Danielopol and Cvetkov, 1979) and the group taurica in East, South and South-west Europe (Danielopol, 1978a). 
Mixtacandona botosaneanui Dan. and Mixtacandona löffleri Dan. occurring in the Lower Danube Valley, in Romania, are closely related to Mixtacandona transleithanica (Löffler) and Mixtacandona laisi vindobonensis (Löffler) occuring in or near the Upper Danube Valley, in Austria (Löffler, 1960, 1963, 1964, Danielopol, 1976, 1978b).

The distribution of other subterranean Candoninae occurring in or near the Lower Danube Valley in Romania differ from those found in the Upper Danube Valley in Austria e.g. Mixtacandona pietrosanii Dan \& Cvetk. does not occur in Austria (Danielopol and Cvetkov, 1979); Pseudocandona serbani Dan. is very common in Romania but rare in Lower Austria (Dancau and Danielopol, 1972, Danielopol, 1976, 1978b). Cryptocandona kiefferi (Klie) which is common in Austria (Löffler, 1963, Danielopol, 1976) has never been found in Romania.

\section{RESUME}

On présente la description de Mixtacandona botosaneanui, Mixtacandona löffleri et Phreatocandona motasi. Les deux premières espèces appartiennent dans le Sud-Ouest de la Roumanie, dans ou près de la Vallée du Bas-Danube. Phreatocandona motasi vit dans l'aquifère poreux de la Vallée de l'Olt à Jiblea au groupe laisi-chappuisi et ont été dans des aquifères poreux et karstiques près de Calimanesti. Des informations biogéographiques sont données sur la distribution des Mixtacandona du groupe laisi-chappuisi et des Candoninae hypogées de la Vallée du Bas-Danube, en Roumanie.

\section{REFERENCES}

BOTOSANEANU, L. and St. NEGREA 1972. Pesterile explorate in: VULCANESCU, R. ed: Atlasud «Portile de Fier»: p. 152, fig. 17, Edit. Acad. R.S. Romania, Bucharest.

DANCAU, D. 1971. Sur un nouvel Amphipode souterrain de Roumanie, Niphargus alutensis n.sp.. Trav. Inst. Spéol. «E. Racovitza», 10:209-215.

DANCAU, D. and D. DANIELOPOL, 1972. Fauna de Crustacee din apele subterane: Amphipoda, Ostracoda. In: VULCANESCU, R. ed: Atlasud «Portile de Fier». p. 155-156, fig. 21, Edit. Acad. R.S. Romania, Bucharest.

DANIELOPOL, D. 1976. The distribution of the fauna in the interstitial habitats of riverine sediments of the Danube and the Piesting (Austria). Int. J. Speleol., 8:23-51.

DANIELOPOL, D. 1978a. Ostracodes hypogés du Sud de la France. 1. Mixtacandona juberthieae n.sp.. Int.J. Speleol. 9:235-249.

DANIELOPOL, D. 1978b. Ueber Herkunft und Morphologie der süsswasserhypogäischen Candoninae (Crustacea, Ostracoda). Sitz. Ber. Oesterr. Akad. Wiss. Math Nat. K1. Abt. I. 187:1-162.

DANIELOPOL, D. and L. CVETKOV 1979. Trois nouvelles espêces du genre Mixtacandona (Ostracoda, Cyprididae, Candoninae), Hydrobiologia, 60. 67: 249-266, 
KLIE, W. 1943. Ostracoden aus dem Grundwasser der Umgebung von Kolozvar. Fragm. Faun. Hung. 6:35-41.

LOEFFLER, H. 1960. Die Entomostrakenfauna der Ziehbrunnen und einiger Quellen des nördlichen Burgenlandes. Wiss. Arb. Burgenland 24:1-32.

LOEFFLER, H. 1963. Die Ostracodenfauna Oesterreichs. In: Beiträge zur Fauna. Austriaca. Sitz. Ber. Oesterr. Akad. Wiss. Math. Nat. Kl. 1:199-211.

LOEFFLER, H. 1964. 3 Beitrag zur Kenntnis der Entomostraken burgenländischer Brunnen und Quellen (Südl. Burgenland). Wiss. Arb. Burgenland 31:156-169.

MAZEPOVA, G.F. 1970. A new species of Ostracode from the Baikal Lake and its relation to the transcaucasian subterranean fauna (in russian). Zool. J. 49:1632-1637. 